Dept. of Food Hygiene.

Animal Health Research Institute, Dokki, Giza, Egypt.

\title{
EFFECT OF SUGAR ON ABSORPTION OF ALUMINUM RESIDUE IN FISH
}

(With 5 Tables)

\author{
By \\ AMAL A. SHEHATA; HALA ALI and AMANI L.A. HEMA \\ (Received at 15/9/2011) \\ تاثير السكر فى أمتصاص بقايا مادة الألومنيوم فى الأسماك \\ أمل على شحاته ، هالهه على ، أمانح لطفى حما

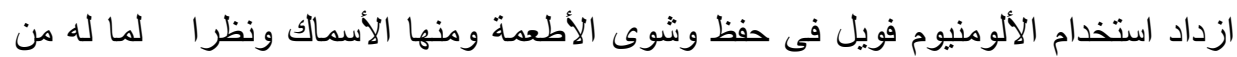

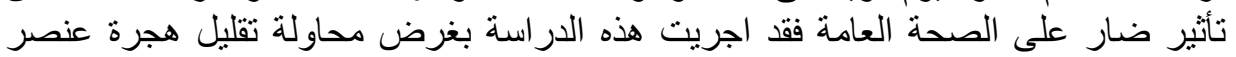 \\ الألومنيوم من الألومنيوم فويل الى الأسماك باستخدام مادة طبيعية لا تؤثر على على طعم الألى الأسماك

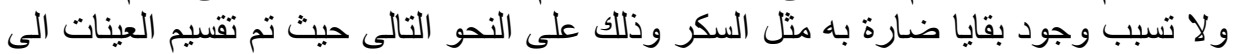

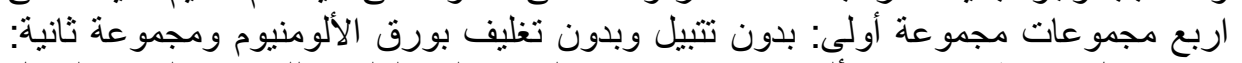

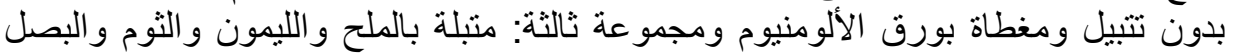

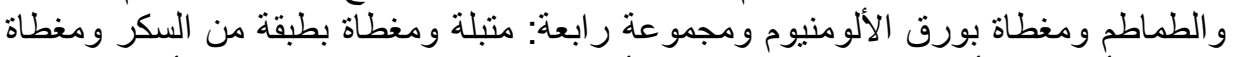

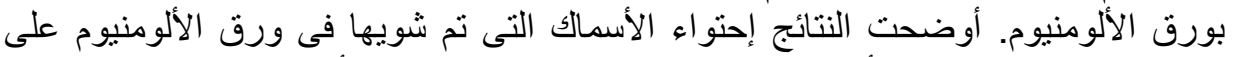

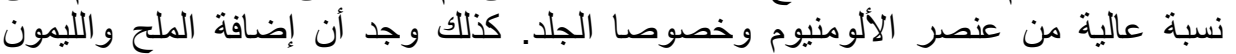

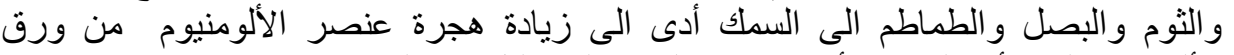 \\ الألومنيوم إلى الأسماك بينما أدت إضافة السكر الى تقليل هذه النسبة.
}

\section{SUMMARY}

The effect of sugar on absorption of aluminum (Al) residue in Tilapia was studied. This work was carried out on 28 random tilapia fish samples. Samples were divided into four groups (seven for each group) where the $1^{\text {st }}$ group fish were grilled without additives and without wrapped with aluminum foil while the $2^{\text {nd }}$ group, fish were grilled without additives but wrapped with aluminum foil. The $3^{\text {rd }}$ group, fish were grilled with adding salts, onion, tomato, garlic and lemon, then wrapped with aluminum foil, while the $4^{\text {th }}$ group, fish were grilled with adding salts, onion, tomato, garlic and lemon, then 5\% sugar from weight of fish were spread on the whole fish surface and wrapped with 
aluminum foil. Samples were grilled in oven at $180^{\circ} \mathrm{C}$ for $20 \mathrm{~min}$. Each sample was divided into 2 parts; skin and muscle. The results showed that the highest level of aluminum residue in fish grilled with addition of salts, onion, tomato, garlic and lemon, while addition of sugar reduced migration of aluminum into the skin and muscle of fish.

Key words: Fish, aluminum residue, aluminum foil, sugar.

\section{INTRODUCTION}

Fish is considered one of the most important food stuffs, they are the cheapest source of animal protein in many countries. Fish have protein of high biological values as they contain essential amino acids and good source of minerals such as calcium, phosphorus, iron and trace elements like Iodine, as well as, vitamins, in addition to the content of polyunsaturated fatty acid (Sedik et al., 1989)

Aluminum is widely used for manufacturing household utensils and packaging materials. Aluminum foil is widely used for packing, storing and cooking of various foods. Especially, it is common practice to wrap meat and fish and grill or cook them in the oven in order to prevent water up take (McWilliams, 1989) and avoid direct heat (Ranau et al., 2001). The widespread use of aluminum foils makes them a significant potential source of dietary aluminum.

The extent of the increase of aluminum is dependent on several factors such as $\mathrm{PH}$ of the food and/or cooking medium, temperature, duration of contact or heating, presence of sugar, organic acids, salts and other ions (Ranau et al., 2001).

Aluminum toxicity is well known in patients with long standing chronic renal failure (Meiri et al., 1993), aluminum has also been associated with several skeletal osteomalacia and neurological failures e.g; Alzhemier's disease (Gauthier et al., 2000; Rondeau et al., 2000; polizzi et al., 2002; Miu et al., 2004; Gupta et al., 2005).

Regarding the suggested provisional tolerable daily intake of $1 \mathrm{mg} \mathrm{Al} / \mathrm{Kg}$ body weight per day of the $\mathrm{FAO} / \mathrm{WHO}$ Expert Committee on food additives (FAO/WHO, 1994), it can be stated that there is no evident risk to health of consumer. However, it is possible that excessive consumption of foods packed with aluminum foil may carry a health risk. 
In recent years, it is common practice to wrap the meat and fish prior to oven cooking. Due to possible relation between aluminum uptake and the specific diseases mentioned above, it is important to determine the aluminum concentration of food wrapped with aluminum. This study was conducted to detect the levels of aluminum content in fish packed with aluminum foil and grilled in oven and try to decrease the migration of aluminum to fish by using sugar.

\section{MATERIALS and METHODS}

A total of 28 samples of fresh Tilapia fish were collected randomly from shops at Giza-Egypt. Samples were transferred under strict hygienic measures to laboratory as soon as possible where they were subjected to suitable preparation.

Samples were divided into four studies (seven for each study), $1^{\text {st }}$ study, fish were grilled without additives and without wrapped with aluminum foil, $2^{\text {nd }}$ study, fish were grilled without additives but wrapped with aluminum foil, $3^{\text {rd }}$ study, fish were grilled with addition of salts, onion, tomato, garlic and lemon, then wrapped with aluminum foil, $4^{\text {th }}$ study, fish were grilled with addition of salts, onion, tomato, garlic and lemon. Five percentage of sugar from weight of fish were spread on fish surface and wrapped with aluminum foil. Samples were grilled in oven at $180^{\circ} \mathrm{C}$ for $20 \mathrm{~min}$. Each sample was taken from 2 parts; skin and muscle.

Each sample was minced and homogenized then analyzed for aluminum content by wet oxidation method, according to AOAC (1990) by using a Perkins Elmer 2380 Atomic Absorption Spectrophotomter at wave length 309 , temp. $2900-3000^{\circ} \mathrm{C}$ with nitrous oxide and acetylene.

The data obtained from four groups were analysed by one -way ANOVA using the SPSS statistical package program, and difference among the individual means were compared using LSD range test (SPSS, 2007). 


\section{RESULTS}

Table 1: Level of aluminum content (ppm) in $1^{\text {st }}$ group (fish grilled without additives and without wrapping with aluminum foil):-

\begin{tabular}{|l|c|c|c|}
\hline Samples & MIN & MAX & Mean \pm SE \\
\hline Skin & 0.18 & 0.982 & $0.646 \pm 0.1$ \\
\hline Muscle & 0.112 & 0.395 & $0.179 \pm 0.03$ \\
\hline
\end{tabular}

Table 2: Level of aluminum content $(\mathrm{ppm})$ in $2^{\text {nd }}$ group (fish grilled without additives but wrapped with aluminum foil):-

\begin{tabular}{|c|c|c|c|}
\hline Samples & MIN & MAX & Mean \pm SE \\
\hline Skin & 0.101 & 0.26 & $0.160 \pm 0.02$ \\
\hline Muscle & 0.09 & 0.21 & $0.158 \pm 0.01$ \\
\hline
\end{tabular}

Table 3: Level of aluminum content (ppm) in $3^{\text {rd }}$ group (fish grilled with addition of salts, onion, tomato, garlic and lemon and wrapped with aluminum foil):-

\begin{tabular}{|l|c|c|c|}
\hline Samples & MIN & MAX & Mean \pm SE \\
\hline Skin & 0.816 & 3.53 & $1.731 \pm 0.36$ \\
\hline Muscle & 0.332 & 0.713 & $0.560 \pm 0.06$ \\
\hline
\end{tabular}

Table 4: Level of aluminum content (ppm) in $4^{\text {th }}$ group (fish grilled with addition of salts, onion, tomato, garlic, lemon with spreading of sugar on surface of fish and wrapped with aluminum foil):-

\begin{tabular}{|c|c|c|c|c|}
\hline Samples & $1^{\text {st }}$ group & $2^{\text {nd }}$ group & $3^{\text {rd }}$ group & $4^{\text {th }}$ group \\
\hline Skin & $0.160^{\mathrm{a}}$ & $0.646^{\mathrm{b}}$ & $1.731^{\mathrm{c}}$ & $1.401^{\mathrm{d}}$ \\
\hline Muscle & $0.158^{\mathrm{a}}$ & $0.179^{\mathrm{a}}$ & $0.560^{\mathrm{b}}$ & $0.308^{\mathrm{c}}$ \\
\hline
\end{tabular}


Table 5: statistical analysis

\begin{tabular}{|l|c|c|c|}
\hline Samples & MIN & MAX & Mean \pm SE \\
\hline Skin & 0.51 & 2.19 & $1.401 \pm 0.25$ \\
\hline Muscle & 0.202 & 0.514 & $0.308 \pm 0.04$ \\
\hline Samples & MIN & MAX & Mean \pm SE \\
\hline Skin & 0.51 & 2.19 & $1.401 \pm 0.25$ \\
\hline Muscle & 0.202 & 0.514 & $0.308 \pm 0.04$ \\
\hline
\end{tabular}

No significant difference $(\mathrm{P}<0.05)$ between cells contain same letter in the same row.

\section{DISCUSSION}

The obtained results showed the migration of aluminum from aluminum foil to skin of fish more than the muscle due to the skin was directly contact to aluminum foil. Table 1 revealed that the mean values of aluminum contents in fish (skin and muscle) grilled without additive and without wrapping with aluminum foil were $0.160 \pm 0.02$ and $0.158 \pm$ $0.01 \mathrm{ppm}$; respectively.

The results in Table2 showed the mean values of aluminum content in $2^{\text {nd }}$ group, fish were grilled without additives but wrapped with aluminum foil in skin and muscle were $0.646 \pm 0.1$ and $0.179 \pm$ $0.03 \mathrm{ppm}$; respectively. Significant differences was showed as increasing in aluminum residues in skin of fish in the $2^{\text {nd }}$ group at $(\mathrm{P}<0.05)$, while no significant differences at $(\mathrm{P}<0.05)$ between muscles in $1^{\text {st }}$ group and 2 nd group due to migration of aluminum from aluminum foil into fish skin and muscle during grilled which increase by temperature. Other researches stated that cooking in aluminum utensils or aluminum foil increased the aluminum concentration of foods (Ranau et al., 2001; ElZeini and Hosny, 2003; Diab, 2005; Turhan, 2006; El-Mossalami and Noseir, 2009; Mohamed and Noiser, 2009).

The level of aluminum content in $3^{\text {rd }}$ group, fish grilled with addition of salts, onion, tomato, garlic and lemon then wrapped with aluminum foil were shown in Table 3 . The mean value of aluminum content in skin and muscle were $1.731 \pm 0.36$ and $0.560 \pm 0.06 \mathrm{ppm}$; respectively. the results were agreed with Gramiccioni et al. (1996); Diab (2005); El-Tabiy (2010). From this result, it is evident that 
significant increased in skin and muscles of fish grilled in the $3^{\text {rd }}$ group at $(\mathrm{P}<0.05)$ as compared with the $2^{\text {nd }}$ group Table 5. From the present data, it could be concluded that acidic and salted foods increased the migration of aluminum into foods as a result of enhancing chemical and/or electrochemical corrosion. Shuping (1996) reported that aluminum concentration increased due to chemical corrosion by acids and alkalis during boiling and storage for short periods. Takeda et al. (1998) reported aluminum migration from aluminum pan into foods increased by increase temperature and addition of acidic foods (including orange and tomato juice, yoghurt and different types of pickles and vinegars) but was reduced by presence of proteins, amino acid, sugar or cholesterol.

Table 4 showed the Level of aluminum content in $4^{\text {th }}$ group, fish that grilled with addition of salts, onion, tomato, garlic and lemon, then $5 \%$ sugar from weight of fish were spreaded on the whole fish surface and wrapped with aluminum foil in skin and muscle were $1.401 \pm 0.25$ and $0.308 \pm 0.04 \mathrm{ppm}$; respectively. From Table 5, it is evident that significant decreased in skin and muscles of fish grilled in the $4^{\text {th }}$ group at $(\mathrm{P}<0.05)$ as compared with $3^{\text {rd }}$ group, this may be attributed to that the level of aluminum migration from aluminum foil was reduced by addition of sugar. The hypothesis reported by Takeda et al. (1999) who stated that the level of aluminum migration from thick aluminum foil to chicken meat samples, and the addition of molasses which considered as a source of sugar decreasing the migration of aluminum from aluminum foil to food. These data are agreement with those reported by GabAlla (1998) who repoted that the migration of aluminum from an aluminum pan into food was greater compared with stainless steel. Acidic and salty foods caused greater migration of aluminum into the foods during cooking, while addition of sugar reduced migration of aluminum into the foods. Also, El-Zeini and Hosny (2003), reported that, covering chicken meat samples with molasses before wrapping in thick aluminum foil, resulted in decreasing aluminum migration in the chest and thigh muscles by (7-5\%) respectively, if compared with non molasses covered meat wrapped in thin (67-30\%) and thick (40-21\%) aluminum foils respectively.

It could be concluded after estimation of aluminum residue in each of the four grilled fish groups that the fish group grilled without aluminum foil wrap was the best one concerning the aluminum residue 
followed by fish group that grilled with aluminum foil warp and sugar addition.

The group of fish that grilled using aluminum foil with additives was the least one. It was also concluded that spreading of sugar on surface of fish has successfuly decreased aluminum migration from aluminum foil to fish.

On the other hand it is recommended to either remove the skin of fish after grilling or spreading sugars along the fish surface in condition of eating fish grilled with aluminum foil.

FAO/WHO Expert Committee on food additives (FAO/WHO, 1994), conclude that the daily intake of aluminum in children is 2$6 \mathrm{mg} / \mathrm{Kg}$ and in adults $6-14 \mathrm{mg} / \mathrm{Kg}$. Regarding the body weight (WHO, 1989) suggested tolerable daily intake of $1 \mathrm{mg} / \mathrm{Kg}$ body weight and there is no evident risk to health of consumer from eating $200 \mathrm{mg}$ daily of cooked meat prepared by aluminum foil.

\section{REFERENCES}

AOAC. (1990): Official Methods of Analysis $15^{\text {th }}$ Ed. Assoc. of Official Analytic Chemists, Washington, Dc.

Diab, O.M. (2005): Monitoring of aluminum residues in cooked meat. J. Assiut Vet. Med. 51 (105): 100-107.

El-Mossalami, E. and Noseir, Sh.M. (2009): Tracess of aluminum in raw milk and the effect of boiling of milk and storage in the aluminum utensils. J. Assiut Vet. Med. 55 (121): 172-179.

El-Tabiy, A.A. (2010): Assessment of aluminium residues in meat cooked in aluminium utensils. Assiut Veterinary Medical Journal. 56 (126): 96-104.

El-Zeini, S. and Hosny, A.M. (2003): Incidance of aluminum in chicken meat cooked by aluminum foil. J. Egypt Vet. Med. 63 (4): 125-132.

FAO/WHO. (1994): Summary evaluations performed by the Joint FAO/WHO Expert Committee on Food Additives (JECFA).

GabAlla, A.A. (1998): Evaluation of aluminum migration from cooking utensils into food. Egyptian Journal of Food Science. 26/28: 73-80.

Gauthier, E.; Fortier, I.; Courchesne, F.; Pepin, P.; Mortimer, J. and Gauvreau, D. (2000): Aluminum forms in drinking water and 
risk of Alzhemier's disease. Environmental Research, 84: 234-246.

Gramiccioni, L.; Ingrao, G.; Milana, M.R.; Santaroni, P. and Tomassi, G. (1996): Aluminum levels in Italian diets and in selected foods from aluminum utensils. Food Additives and Contaminants 13(7): 767.

Gupta, V.B.; Suram, A.; Hegde, M.L.; Zeca, L.; Garruto, R.M. and Ravid, R. (2005): Aluminum in Alzhemier's disease: are we still at a crossroads? CMLS Cellular and Molecular Life Sciences, 62: $1-16$.

McWilliams, M. (1989): Foods: Experimental perspective. New York: Macmillan Publishing Company.

Meiri, H.; Banin, E.; Roll, M. and Rousseau, A. (1993): Toxic effects of aluminum on nerve cells and synaptic transmission. Progress in Neurobiology, 40: 89-121.

Miu, A.C.; Olteanu, A.I. and Miclea, M. (2004): A behavioral and ultra structural dissection of the interference of aluminum with aging. J. of Alzhemier,s disease, 6: 315-328.

Mohamed, H.SH. and Nosier, Sh.M. (2009): Estimation of some heavy metals in chicken shwarma. Egypt, J. Comp. Path. \& Clinic. Path. 22 (3): 24-36.

Polizzi, S.; Pira, E.; Ferrara, M.; Papleo, A. and Albera, R. (2002): Neurotoxic effects of aluminum among foundry workers and Alzhemier,s disease. Neurotoxicology, 23: 761-774.

Ranau, R.; Oehlenschlager, J. and Steinhart, H. (2001): Aluminum levels of fish fillets baked and grilled in aluminum foil. Food Chemistry, 73: 1-6.

Rondeau, V.; Commenges, D.; Jacqmin-Gadda, H. and Dartiguse, J.F. (2000): Relation between aluminum concentrations in drinking water and Alzhemier,s disease: an 8-year follow -up study. Amican J. of Epidemiology, 152: 59-66.

Sedik, M.F.; Safwat, E.E.; Ibrahim, A.M. and Shaban, A.E. (1989): Studies on some species of locally produced fish. Vet. Med. J. Giza, 37(2): 197-207.

Shuping, B. (1996): A model describing the complexing effect in the leaching of aluminum from cooking utensils. Environ. Poll. 92 (1): 85.

SPSS (2007): SPSS for Windows. Release, 16.0.1 Standard Version. SPSS INC. 
Takeda, Y.; Kawamura, Y. and Yamada, T. (1998): Dissolution of aluminum from aluminum foil into foods and effect of components on the dissolution. J. of the Food Hygienic Society of Japan, 39: 266-271.

Takeda, Y.; Kawamura, Y. and Yamada, T. (1999): Migration of aluminum from disposable aluminum foil vessels into food, J. of the Food Hygienic Society of Japan, 40: 172-177.

Turhan, S. (2006): Aluminum contents in baked meats wrapped in aluminum foil. J. Meat Science 74: 644-647.

WHO "World Health Organization" (1989): Toxicological evaluation of certain food additives and contaminants. Food additives series (Vol.24, 116-117) University Press, Cambridge. 